\title{
REGULATION OF CONSUMER CREDIT - THE CREDIT CARD AND THE STATE LEGISLATURE
}

TнE credit card industry, along with other businesses offering consumer credit $^{1}$ to the American public, is enjoying rapid, widespread success. ${ }^{2}$ A variety of plans exist; while the most widely known are national plans such as Diners' Club, the greatest expansion within the industry is occurring on the local level. ${ }^{3}$ There, the card has been adopted as an instrument for the extension of revolving credit in the purchase of all types of consumer goods and services, offering the consumer a method of distributing expenses over a period of time through installment payments. Although most states have a wide range of legislation which regulate consumer finance, only one state, thus far, has singled out these credit card plans for specific regulatory treatment.. Whether and to what extent regulation of the consumer finance aspects of these plans is desirable, and the degree to which any necessary regulation can be effected under existing laws, is the subject of this Note.

Credit cards were first issued by individual department stores and by national petroleum companies. ${ }^{5}$ These cards were used solely as sales devices, providing the consumer the convenience of consolidation of payments. With the birth of the Diners' Club in 1950, the credit card first found use as an independent source of profit. ${ }^{6}$ For a nominal yearly fee, the card issuer pro-

1. "Consumer credit," as used herein, embraces all loans of money or credit to individuals which provide purchasing power for household, family, or other personal goods, both durable and non-durable, and services, and which are repayable either by a single payment or on an installment basis. Real estate mortgage loans are excluded.

2. Since World War II consumer credit has increased from approximately $51 / 2$ billion dollars to over 66 billion dollars. 49 FED. Reserve BuLL. 1442 (1963). Credit card plans not offering an installment payment plan accounted for 571 million dollars of a total of 14,716 million dollars in non-installment credit outstanding in 1963; plans which offer installment credit are not accounted separately by the Federal Reserve Board. Id. at 1443. While it may be too early to judge the long-range influence of the credit card, its present popularity is reflected in the estimated 57 million cards in use. BLACK, BuY Now, Pay Later 16 (1962).

3. One indication of such expansion can be seen in the growth of the Bank of America's statewide credit card, "BankAmericard," which in 1962 accounted for over 85 million dollars in sales and advances in California. BANK of ANERICA, ANnual Report 19 (1962). There are more than $1 \frac{1}{4}$ million BankAmericard cardholders, who are able to use the cards at over 35 thousand retail, service, and professional establishments. Bank of America, BankAmericard Fact Sheet, May, 1963 (on file in the Yale Law Library). [hereinafter cited as Fact Sheet].

4. N.Y. Pers. Prop. LAW art. 10, \& 413(11). See notes 82-95 infra and accompanying text.

5. For a detailed description of the development of credit cards, see Comment, The Tripartite Credit Card Transaction: A Legal Infant, 48 CaLIF. L. REv. 459, 460-63 (1960).

6. The birth of the Diners' Club has been described as a monument to American ingenuity, its founding purportedly the result of a forgotten wallet at a restaurant! See BLACK, op. cit. supra note 2, at 12-14. Such ingenuity was later extended to the use of credit cards for tax deduction record purposes. Wall Street Journal, Feb. 21, 1958, p. 1, 
vided the card holder with a line of credit which would be honored by a great number of merchants. The issuer made his profits by purchasing at a discount all holders' sales vouchers from the merchants. Still, there was no extension of credit beyond the lapse between purchase and billing. If the monthly statement was not promptly paid in full, membership privileges would be cancelled.?

New credit card systems couple the convenience aspect of monthly billing with a form of installment finance. The issuer becomes a lender as well as a central billing agency. ${ }^{8}$ Through a revolving credit account, ${ }^{9}$ a certain amount

col. 1. And the clever use of credit cards by the American thief must not be overlooked. See Life, June 1, 1959, p. 119. Twenty-three states have passed legislation making it a criminal offense to steal or use stolen credit cards. NAtional Assoctation of CREDIT Management, Credit Manual of Commercial Laws xxi-xxii (1963).

7. Information on credit card mechanics is derived from materials received from various credit card companies, on file the Yale Law Library.

8. The mechanics of such plans are found in the three contracts which are used. The card issuer and card holder contract is usually found on the application form submitted by the prospective holder; it generally provides that amounts charged are owed directly to the issuer rather than to the merchant, that full payment may be made (generally within 25 days) with no finance charge involved, or that payments may be made on a revolving account basis, with a minimum of $10 \%$ of the outstanding balance and $\$ 10$ each month (if less than $\$ 10$ it must be paid in full) and with a finance charge of $1 \frac{1}{2} \%$ per month on the declining unpaid balance. Other common provisions include an obligation from the holder to pay reasonable attorney's fees if collection of overdue accounts is necessary, responsibility of the holder for payment for goods purchased with lost or stolen cards until the company is notified of such a loss, and the waiver of defenses against the issuer which might arise against the merchant in the transaction. For an analysis of contractual waivers of defenses against the issuer in three-party plans, see The Tripartite Credit Card Transaction, stipra note 5, at 471-78. For a general discussion of risk-shifting in credit card transactions, see Comment, Applicability of Exculpatory Clanse Principles to Credit Card Risk-Shifting Clauses, 22 LA. L. Rev. 640 (1962).

The issuer-merchant contract generally provides for the purchase by the issuer of the holders' sales drafts at a discount (ranging from 3-6\%); it also provides that the merchant will honor the credit of the holder of a card, that he will not extend credit over a ceiling without getting the approval of the issuer, that a yearly charge will be paid by the merchant, and that the merchant will be responsible for all defenses, disputes, counterclaims, or offsets with respect to merchandise or services covered by credit card sales. However, the issuer purchases the sales vouchers on a non-recourse basis (the issuer agrees to accept full responsibility for unpaid claims).

The holder-merchant agreement is generally a sales draft which describes the goods or services purchased, unit costs, and total costs; the issuer-holder agreement is generally set out also.

Such information has been derived from materials sent by various credit card companies to the Yale Law Journal, on file in Yale Law Library. See also The Tripartite Credit Card Transaction, supra note 5, at 463-65.

9. Revolving credit was first used by department stores and there are, today, many two-party revolving credit plans. In such plans the seller takes the place of the issuer as the grantor of credit; credit cards are honored only at the seller's store or chain of stores. While the scope of this Note is primarily limited to considerations of the problems in three-party plans, much of the analysis of possible abuses and governmental responses is applicable to the two-party arrangement. 
of credit is extended to the holder, varying with the individual's credit rating; each purchase diminishes the credit available but each installment payment restores the credit pro tanto. ${ }^{10}$ Payments are tusually made on a monthly basis, the consumer having the choice of paying the total indebtedness accrued during that month immediately (with no finance charge) or of paying any amount down to a minimal fraction (usually $10 \%$ ) ; the remainder is paid in monthly installments, with a finance charge applied to the declining principal balance. ${ }^{11}$

Through the creation of these plans, "charge-it" spending opportunities have been presented to a broader segment of the consuming public and a broader range of transactions than occurred under previous plans, which tended to be limited to businessmen and to entertainment expenses. ${ }^{12}$ Credit spending opportunities have also been enlarged, for installment sales in the past were generally limited to durable goods in which a security interest could be maintained $;^{13}$ by presenting the consumer with a method of financing all types of goods, ${ }^{14}$ the new plans give the merchants of non-durable goods an opportunity to provide installment sales to their patrons. The cards have been

10. For example, a holder may be granted a line of credit of $\$ 250$. If he makes purchases of $\$ 100$ in the first month, he may pay the entire $\$ 100$ at billing date; if so, he has $\$ 250$ of credit for the following month. However, he may repay from $\$ 10$ to $\$ 100$ and carry the balance owed to the following month. Thus, if he pays $\$ 20$, his credit for the following month will be $\$ 170$, and he will pay a service charge of $\$ 1.20$ on the $\$ \$ 0$ carried over.

11. Such plans have been called "optional" revolving credit accounts, inasmuch as the holder has the option of paying the total indebtedness each month or establishing an installment payment plan. Earlier plans were of a different nature; the holder paid a service charge on the amount of credit used regardless of the time of payment. Project, Legislative Regulation of Retail Instalment Financing, 7 U.C.L.A.L.Rev. 618, 642-44 (1960).

12. The use of Diners' Club and similar plans ordinarily is limited to charging expenses incurred in restaurants, hotels and motels, and related facilities. Such plans are generally used by businessmen; after an unsuccessful attempt at extending coverage to greater-risk persons, the Diners' Club was forced to weed out shady accounts. Financial World, Mar. 27, 1963, pp. 6-7. On the other hand, the users of the new credit card plans are representative of the entire spectrum of economic classification.

13. See 1 Seligman, The Economics of Installament Selling 197-200 (1927). At present, it does not appear that the new plans use security devices. There is, however, a possibility of using a security interest which covers the entire outstanding indebtedness, or, if there are durable goods involved, the specific goods sold. The latter alternative would present difficulties of allocating what part of the installment payment was to be applied to the goods in which security had been maintained. See Consumer Credit Sympositum: Developments in the Law', 55 Nw. U.L. Rev. 301, 331 n. 9, 347-48 (1960).

14. The extent of goods and services offered is ever expanding. The new credit card plans, in some cases, offer credit for entertainment items, gasoline, clothing, food, household items, automobile and television repairs, and even beauty salons.

Services such as those of doctors and dentists are also offered, and Uni-Serv is attempting to include hospitals in its plan. Letter from John J. Borman, Ass't. Treas., Uni-Serv Corp., to the Yale Law Journal, Oct. 3, 1963, on file in Yale Law Library. (All letters hereinafter cited are to the Yale Law Joumal and are on file in Yale Law Library.) 
issued both by recently organized financial institutions ${ }^{15}$ and by banks seeking to extend their activities further into the consumer finance field. ${ }^{16}$ The issuers derive their profits from discount purchase of sales vouchers as well as the finance charge. Banks as issuers may also benefit by an increase in other business from the merchants and consumers who become acquainted with them. ${ }^{17}$ The merchant, often unable to bear the costs of providing revolving credit on his own, may benefit through expansion of his clientele to include those who need financing, but could not otherwise get it, and those who, for convenience, turn to merchants connected with the plan. The merchants associated with the plans rarely complain. ${ }^{18}$ They are paid immediately by the issuer, who bears, administratively, the risk of unpaid accounts. For the card holders the revolving credit system serves as a substitute for small loans previously used to finance purchases on an installment basis; under some of the plans, it is even possible to obtain a direct loan of money. ${ }^{19}$ The consumer may thus be provided with a cheaper means of financing purchases than borrowing from small loan companies. ${ }^{20}$ Finally, the competition provided small loan companies by the new plans may have the effect of forcing their interest rates down.

15. The largest non-bank credit card revolving charge plan is the Uni-Card Charge Service, promoted by the Uni-Serv Corp. which bought the assets of the Chase Manhattan Bank credit card plan when the latter decided that the venture was unprofitable. Uni-Serv presently operates in four states, and expects to expand to three more states in 1964. Letter from John J. Borman, supra note 14. An attempt by Seaboard Finance Co. to establish such a plan on a nationwide basis ended in failure. Financial World, Nov. 7, 1962, p. 6 .

16. See discussion at note 3 supra. As early as 1959 , it was estimated that 100 banks had already launched credit card programs. N. Y. Times, May 10, 1959, § 3, p. 1, col. 8 . For a general discussion concerning the long-range movement of banks into the consumer credit field, see AMIERICAN INSTITUTE of BANRING, op. cit. supra note 8, at 18-24.

It should be noted that many banks have revolving credit check plans instead of credit card plans. In such plans, the consumer is given a line of credit on which he may write checks, paying for any merchandise or service directly or even getting cash. See Burroughs Clearing House, Jan., 1960, pp. 36-37.

17. Prochnow \& Foulke, Practical Bank Credit 461 (2d rev. ed. 1963).

18. But, in 1958-59 there was a measure of discontent among restaurant owners because of the large percentage of discount exacted by issuers; a concerted effort resulted in a reduction of the discount rate by the Hilton plan. Business Week, Mar. 21, 1959, p. 36.

19. For example, the BankAmericard plan offers loans of money up to $\$ 250$ simply upon presentation of the credit card at one of the bank's branches.

20. Small loan rates vary but are generally between 2 and $3 \%$ per month on the declining principal balance. 1 CCH Installment Credrt Gume $\{41$ (1963). The plans, however, usually charge only $11 \% 2 \%$ per month. There are several reasons why charges may be lower in the new credit card plans. Because the issuer profits from the purchase of cales vouchers from the merchant, the issuer may reduce the charge to the holder. While high operating costs are common to both lenders, the continual relationship between the issuer and the holder, as opposed to the single transaction with the small loan company, enables the issuer to spread the costs over a good many purchases. Furthermore, while small loan companies are faced with the high cost of getting money to lend, banks need cnly pay a comparatively low rate of interest to time-depositors for the use of their money. 


\section{The Need for Regulation}

Consumer loan plans have traditionally shown a potential for misuse. ${ }^{21}$ The revolving credit card plans are no exception - given a powerful issuer, discount rates far in excess of risk or markedly unfavorable contract terms could be foisted upon the merchant subscribers. But the merchant-issuer relationship seems little different from most commercial relationships, and special regulation is hard to justify. Any imbalance in bargaining strength, moreover, may well be overcome by the issuers' need to provide as broad a base for member transactions as is possible. Issuer-consumer relations, analogous to lenderborrower relations generally, seem the more likely source of malpractice and the more likely focus of regulatory concern $;^{22}$ they form the subject of discussion here.

Well-settled areas of regulatory interest arise from frequently catalogued abuses in consumer finance. The history of installment sales and loans has been checkered by the use of misleading statements, inadequate disclosure of payment terms and costs, blank spaces on the initial contract which are later filled in to the consumer's detriment, and the addition to the monthly statement of items not actually purchased. The governmental interest in preventing these activities is clear; active fraud and, what is nearly the same, consumer failure to understand what he is obtaining, through lack of information, involve too great a strain on the premises and operation of a free market to be tolerated. Regulation to prevent such occurrences is orthodox, and its wisdom little questioned.

Government regulation has extended beyond these questions of disclosure and adhesion, to the imposition of axceiling on rates charged by lenders for the use of money. Although such regulation is common, ${ }^{23}$ and it is increasingly

21. Warren, Regulation of Finance Charges in Retail Installment Sales, 68 YALE L. J. 839, 841 (1958). See also State of New York, Message of Governor Averell Harrimin to the Legislature, JaNuary 9, 1957 (Legislative Document No. 1, 1957). For a general discussion of the abuses of loan sharks in the small loan field, see RoBrNson \& NugENT, Regulation of the Sarall Loan Business $48-74$ (1935). See also Hubachek, The Drift Tozuard $A$ Consumer Credit Code, 16 U. CHr. L. Rev. 609, 613 (1948).

22 . While there are many possible abuses, it could be argued that the issuers of the new credit cards must operate with the highest ethics. Most plans are operated by banks, which must be careful not to impair their good will in the community through abuses in one or all phases of their operations. Moreover, since the success of a credit card operation is dependent upon having a large number of holders and merchants, the reputation for unethical practice must be avoided. While fraudulent practices may thus be prevented, the "ethics" in charging cardholders is not clearly definable. While the ChaseManhattan Bank's charge plan (CMCP) was discontinued because it could not operate profitably with a $1 \%$ per month service charge and because it was determined that a higher rate would be "exorbitant," the Bank of America has been operating with a $11 / 2 \%$ per month service charge, as does Uni-Serv, which bought the Chase-Manhattan assets. See Business Week, Nov. 3, 1962, pp. 65-66.

23. The earliest of such laws were the usury laws. The last three decades have produced a flurry of "consumer protection" legislation, including small loan acts, retail installment sales acts, credit union acts, credit insurance acts, and the like. Much has 
clear that this type of regulation will be used to limit transactions under the new revolving credit plans, the premises upon which it is based are open to doubt. Basically, the fervor that underlies recurrent demand for regulation of rates rests on the view, first put forward under a religious warrant, that money-lending is an immoral transaction. ${ }^{24}$ Several arguments have been articulated to support this inclination for rate regulation. Financial institutions, it is said, monopolize money and, as such, are, like railroads and power companies, "affected with the public interest."25 Yet, although monopoly power may have been present when banks were few in number and the sole institutions of private finance, banks at present are highly competitive, among themselves and with such other financial institutions as small loan companies, credit unions, and installment sales finance companies. ${ }^{26}$

More substantial bases for setting a ceiling on the price of credit may appear to be found by shifting the focus from the seller ${ }^{27}$ to the consumer of credit services. Here, the fear of "overreaching" "needy people" desperate for the wherewithal to survive is predominant $;^{28}$ the loathsome image of the merchant

been written on the legislation. See generally, BARRETT \& ULRICH, INDEx to LEGAL LITERature on Regulation of Consumser Installasent Lending and on Usury Laws (1948).

24. The view that money lending at interest was an immoral transaction first caused a total prohibition of all money lending, being judged at first as a sin of avarice or uncharitableness, but later as a sin of injustice. NooNan, THE Scholastic ANalysis of Usury 14 (1957). See also Ryar, UsuRy AND UsuRy Laws 37-47 (1924). However, loans of money are not generally frowned upon by religious leaders today, unless such loans are accompanied by fraudulent practices or unjust exactions. NooNAN, supra at $392-93$.

25. See Friedman, The Usury Laws of Wisconsin: A Study in Legal and Social History, 1963 WIs. L. Rev. 515, 520.

26. While many different types of consumer credit companies exist, they are not always competing with one another, although competition among companies lending to the same class of persons is marked. The bank may extend credit or loan money at low rates to persons in higher income brackets and, therefore, lower risk brackets, while the small loan companies will extend credit to persons representing greater risks at higher rates; the area of overlap is difficult to define. See National Consumer Frnance Association, The Consumer Finance Industry 29-31 (1962). On the other hand, retail installment sales of durable goods allow the retention of a security interest so that the lender of credit may cut across all types of borrowers at the same rate. The new credit card plans themselves, offering credit for some durable goods but mostly nondurable goods and services, provide competition to lenders of money, and, if they also include loans of money, are an obvious competitor.

27. Those who deal in money cannot be segregated into a special class of "nonproductive" entrepreneurs, who deserve regulation because they merely shift a commodity from one pocket to another. Other middle-men, such as wholesalers and distributors, also funnel commodities from one group to another for a charge; by so doing, all such entrepreneurs perform valuable social functions, such as the facilitation of efficient distribution.

28. RYAN, op. cit. supra note 24 , at 181 . Ryan's analysis looks to usury laws as a means of protecting the debtor from being oppressed rather than as "rate-regulating" legislation; his criticism is directed at laws which "mistakenly" attempted to prevent overreaching by limiting rates. Ryan felt that the debtor's necessitous condition caused 
of debt getting rich from the toils of the poor provides a substantial impetus to cut back his profit. ${ }^{29}$ But sellers of goods also "profit" from the "toils of the poor." A justification for regulation in one activity must be able to explain its absence in the other. Distinction in treatment would be justified if the competitive mechanism operated more successfully in the sale of goods than in the sale of credit. If such a distortion existed, it would normally arise from one of two sources: imperfect consumer knowledge about conditions in an industry which has the potential to be highly competitive;30 or imperfect consumer ability to deal with knowledge available to him, because of the consumer's particular circumstances. Each deserves further consideration.

It is generally accepted that borrowers do not "shop" for loans, although consumers generally do shop for goods, ${ }^{31}$ and that market mechanisms will, therefore, fail to determine the price of credit. ${ }^{32}$ This imputed failure by consumers of credit to compare rates could be the result of several factors. The different methods of quoting rates adopted by lenders render comparison a difficult task. ${ }^{33}$ Borrowers may believe that it is impossible to understand the

him to turn to people - loan sharks - who would force upon him rates higher than provided by the law.

See also Jenkins v. Dugger, 96 F.2d 727, 729 (6th Cir. 1938).

29. While it might be objected at the onset that the new credit card plans do not involve "needy people" or "necessary goods," both categories are subject to definitional expansion. Persons who are "needy" do not have sufficient funds to buy necessities; to the extent that the classification of necessities is increased, the number of needy people is increased. With total consumer reliance upon goods such as appliances and furniture, and increasingly felt psychological needs, the category of necessities and needy people can be said to include those using the new plans.

30. While few commodities are marketed in what might be called "perfect competition," to approach such an economic state there must be mumerous persons selling identical products. Samuelson, Economics 516 (5th ed. 1961). There has been a marked increase in the number and types of institutions offering loans of money and credit to consumers. See National Consumer Finance Assoctation, The Consumer Finance Industry 13-30 (1962).

Furthermore, a low supply of goods will give rise to higher prices. Samuezson, supra at 413-16. But, the supply of money available to lenders is sufficient to allow competitive pricing.

Even within the credit card industry itself, there may be competition. Issuers are prevented by the anti-trust laws from procuring an agreement from the merchant-members that they will not deal concurrently with other credit card companies. See 15 Personal Finance L. Q. Report 58 (1961).

31. Phelps, Monopalistic and Imperfect Competition in Consumer Laans, $8 \mathrm{~J}$. of Marketing 382, 390 (1944). See also Shuchman, Consumer Credit By Adhesion Contracts II, 35 TEMP. L. Q. 281, 309-10 (1962). However, there have been few empirical studies made of consumer knowledge of costs of borrowing, although existing surveys point to inadequate knowledge. See Due, Consumer Knozoledge of Installment Credit Charges, $20 \mathrm{~J}$. of Marketing 162 (1955).

32. Phelps, supra note 31 , at $390-91$ and authorities cited therein. See also NatronaL Consumer Finance Association, op. cit. supra note 30, at 27.

33. Phelps, supra note 31 , at 387-93. 
rates, ${ }^{34}$ or that the price of credit is basically the same everywhere; they may rely on the lender's good faith or on state regulation which they assume to be present. But such conditions would not justify imposition of a rate ceiling. To the extent that borrowers do not compare rates because of inability to comprehend them, whether because the rates are hidden or because they are complex, enforced disclosure of terms seems a more fitting legislative response. Enforced disclosure, as opposed to rate regulation, focuses directly on the underlying problem of consumer education. Only in the last resort would it seem proper to consider that the complexity of a transaction, as distinguished from the power that may arise from a conjunction of monopoly and need, justifies placing a ceiling on the rates to be charged.

A firmer prop for such regulation may be found in the fear that some people may not be dissuaded from borrowing, even when it is unreasonable for them to borrow because of inability to repay, and the fact that rates will inevitably rise with risks. As a class, persons who can lose by borrowing tend to be high risks, so setting a rate maximum may serve to effectuate a public policy of cutting off their credit entirely. No matter how much some borrowers know as a result of disclosures made to them as to rates, present demands on them may be so great that they are unable to gauge realistically the long term costs of borrowing. ${ }^{35}$ This stress may be most strongly present where the borrower is seeking not to purchase new goods, but to refinance old debts; unwilling to give up that for which he has already paid substantial sums, he is driven to add to his costs of debt financing without obtaining an increase in his tangible estate. If many borrowers overextend themselves in this way, a social interest develops. The rates offered may be competitive and "reasonable" in relation to the risk involved; but a moral judgment can be made that these borrowers should not be allowed to risk their all. Use of an interest-level ceiling to enforce such a judgment would, however, reflect an unusually paternalistic attitude toward adult citizens, and would be a drastic step in curtailment of freedom of choice. Further, it is likely to prove its own worst enemy. Assuming their need for credit to be severe, pushing high risks out of the "legitimate"

34. It is probable that understanding of interest rates is, in fact, difficult. For an amusing example of such difficulty in which Justice Goldberg (then Secretary of Labor) was unable to calculate interest rates at a Senate hearing, see Hearings Before a Subcommittee of the Senate Committee on Banking and Currency on S. 1740, 87th Cong., $2 \mathrm{~d}$ Sess. 123-24 (1962).

35. See Black, op. cit. sulpra note 2, at 7-8; N.Y. Times, Apr. 10, 1960, p. 58, col. 3. It is questionable whether people are, in fact, over-extending themselves in debt. The credit system, by refusing to grant credit beyond a person's ability to repay, guards against such a result; within the credit card industry itself, elaborate measures are taken to prevent the holder from using more than the credit granted to him. See Business Week, Nov. 3,1962 , p. 68 . Moreover, the best available statistics seem to indicate that repayments on installment debts have kept up with amounts outstanding and at present there is little danger that the individual consumer is unable to repay his debts, even though the amount of installment credit outstanding has risen sharply since World War II. 49 FED. RESERVE BULL. 1444-45 (1963). 
loan market will only expand the market for loan sharks, who add monopoly profits and the costs of law evasion to the "market" price of credit. 38

Rate controls and disclosure requirements do not exhaust the traditional categories of remedial legislation dealing with loan transactions. Fears that "unfair" contractual provisions will be imposed upon the borrower have proved another source of regulation. Even if there were vigorous rate competition, it is doubtful that other terms of lending would be altered in the contest for customers. Involved printed forms do not get read, and when they are read, they are normally not understood. ${ }^{37}$ Waivers of statutory rights and defenses, confession of judgment and wage assignment provisions are not only markedly unfavorable to the consumer but are also likely to appear innocent of dangers. It is important to realize, however, that the concept of overreaching, in this context, is based on a lack of understanding rather than on an inherent lack of bargaining power, and on complex factors which lead to adhesion contracts..$^{38}$ Competition may exist among lenders, but the borrower is unable to compare one agreement with another, and if he attempts to do so, he may find them identical.

Remedies for the imposition of "unfair" contractual provisions may take both legislative and judicial form. In addition to preventing fraudulent practices and forbidding clauses felt to be too one-sided or difficult of comprehension, legislation could require complete disclosure in meaningful terms of the initial agreement between the holder and the issuer. The borrower should know the maximum amount of credit available, the fact that the charges are on the amount spent, the method of payment, and the percentage charged for the extension of credit. Any provisions unfavorable to the borrower should be clearly set out and explained so that the agreement may be understood. Courts, recognizing that borrowers will often fail to read the fine print, and that disclosure will, therefore, be ineffective, can refuse enforcement of the provisions in the absence of proof that the consumer was aware of the contractual clause in question - a course of action increasingly familiar in the consumer context. ${ }^{39}$ Such judicial technique, applying pressure on the lender

36. The history of statutory interest rate ceilings would indicate that such legislation was not intended to cut off people from lending sources, but rather to supply them with loans from "legitimate" lenders; this was, in fact, the rationale for increasing rate ceilings for small loans. See note 55 infra and accompanying text.

37. See Due, supra note 32, at 164-65. See also Shuchman, supra note 32, at 309-310.

38. For an analysis of the problems inherent in form contracts which are similar throughout an industry, see Kessler, Contracts of Adhesion - Some Thoughts on Frecdom of Contract, 43 CoLum. L. REv. 629, 632 (1943). See generally, Shuchman, supra note 31 .

39. Cutler Corp. v. Latshaw, $374 \mathrm{~Pa} .1,97$ A.2d 234 (1953) (confession of judgment buried in fine print on reverse side of contract not enforced); McKinney v. Boston \& M. R.R., 217 Mass. 274, 104 N.E. 446 (1914) (contract not enforced where party unable to read). However, the general rule is that one is bound by all the terms of a contract once it is signed. See Shulman v. Moser, 284 I1l. 134, 119 N.E. 936 (1918) (illiterate person bound by contract unless fraud proven); acceptance of a document also binds 
to ensure that the borrower is aware of the provisions, plus legislation ensuring that the provisions are comprehensible, would offer borrowers substantial protection against all but their own folly.

\section{The Possibility of Control Under Existing Legislation ${ }^{40}$}

The usury laws ${ }^{41}$ are one possible source for regulation of the new credit card plans. Such laws traditionally have limited the rate of interest which may be charged for loans of money $;^{42}$ their only disclosure requirement is that the rate of interest appear in a contract. ${ }^{43}$ The maximum rates permitted have

the party to the terms contained therein. See Bulakowski v. Philadelphia Saving Fund Soc'y, 270 Pa. 538, 113 Atl. 553 (1921) (person who could not read English bound by terms of bank deposit book).

The problem has arisen in the credit card context. See Union Oil Co. v. Lull, 220 Ore. 412,349 P.2d 243 (1960). While the issue had not been properly raised in the trial court, the court stated that it was a question of fact as to whether the holder was aware of the provisions set forth in the card. 220 Ore. at 420-21, 349 P.2d at 246-47. See Tripartite Credit Card Transaction, supra note 5, at 481-88; Note, 13 StAN. L. REv. 150 (1960) ; Note, 109 U. PA. L. Rev. 266 (1960).

40. At present, applicable legislation consists of state statutes. Those three-party credit card plans promoted by state-chartered banks and independent financial institutions are obviously subject to state regulation. As to national banks, however, there is some question as to both the appropriateness and the constitutionality of state regulation. However, if usury laws are deemed applicable by courts to the new credit card plans, there would be little question as to the appropriateness of such regulation, for Congress has provided that in states where usury laws are in effect, the same rate will be applied to national banks. 13 Stat. 108 (1864), as amended, 12 U.S.C. § 85 (1958). As to other legislation, it is apparent that it may be applied to national banks if it does not interfere with their creation, tend to impair their efficiency as federal agencies, or conflict with federal law. See Russeld, Savings and Loan Associations 558-69 (1960) and cases cited therein. Congressional intent appears to be for national banks to compete with state financial institutions under the same restrictions, so that national banks should be regulated by the same state legislation deemed applicable to other issuers in the new credit card plans.

41. All states but four - Colorado, Maine, Massachusetts, and New Hampshire have statutes which set a maximum rate of interest permissible on loans made with the rate set forth in a contract. 1 CCH INSTALLMENT CREDIT GudDE If 31 (1963). All states have legal maximum interest rates which apply to loans in which there is no contract rate. See, e.g., MaINe Rev. Star. ch. 59, § 209 (1954). The lowest legal rate is 4\%. N.D. CENT. CoDE $\S 47-14-05$ (1960). The usual rate, both legal and contract, is $6 \%$. See, e.g., N.Y. Gen. Bus. Law art. 25, § 370, to be replaced by N.Y. Gen. Obligatrons Law art. $5, \S 501$ (effective September 27, 1964). The highest permissible contract rate is $30 \%$. See R.I. Gen. Laws $§ 6-26-2$ (1956).

42. In many jurisdictions, "interest rate" has been construed to represent the charge for the use of money, exclusive of legitimate charges for services rendered. See, e.g., Silver Homes Inc. v. Marx \& Bensdorf, Inc., 206 Tenn. 361, 333 S.W. 810 (1960). But see Dickey v. Bank of Clarksdale, 183 Miss. 748, 184 So. 314 (1938). Some statutes specifically allow additional service charges. See, e.g., IrL. Rev. STat. ch. 74, \& 4 (1959).

43. This requirement is not imposed upon the parties as such; it is the result of the dual nature of some usury laws which allow different rates of interest if the rate is set out in a contract. See discussion at note 41 supra. 
often been low; as a result they have only been spottily enforced. ${ }^{44}$ When finance charges for extensions of credit in installment sales - usually greater than permissible interest levels under state usury statutes - have been challenged, courts have often refused to apply the statutes, holding that they are designed to regulate loans of money and not extensions of credit. ${ }^{45}$ Looking to installment sales finance techniques, courts have developed a "time-sale" theory entitling a seller to ask one price for a cash sale and another for a sale on terms which include the extension of credit. ${ }^{46}$ Using fiction to defeat fiction, a few courts, recognizing the functional similarity between a loan of credit and a loan of money, ${ }^{47}$ have looked through the time-sale theory, to

44. The problems with usury law enforcement eventually led to the enactment of small loan legislation. See note, 55 infra and accompanying text. Various subterfuges have been employed by some lenders, such as concealing the loan in collateral transactions, to escape the enforcement of usury laws. Hubachek, The Drift Toward a Consumer Credit Code, 16 U. CHI. L. Rev. 609 (1949). And, in many states corporations may not set up usury as a defense. Note, 65 Y ALE L.J. 105 (1955).

45. The distinction was first justified on the theory that the borrower of money was a needy individual and thus had little bargaining strength, thereby making it easy for the lender to overreach him, while the buyer of goods was sought by the seller, the buyer's bargaining position increased because he did not have to buy the goods in question. General Motors Acceptance Corp. v. Weinrich, 218 Mo. App. 68, 78, 262 S.W. 425, 428 (1924). The distinction was further advanced on linguistic terms: the legal definition of usury had been a loan or forbearance of money at an excessive rate of interest, and the courts pointed out that there was no money received by the buyer (hence no loan) nor was any money due until the date of the installment (hence no forbearance.) Hafer v. Spaeth, 22 Wash. 2d 378, 156 P.2d 408 (1945).

The theory that goods purchased through installment sales are luxuries has been criticized as anachronistic in modern society. Warren, supra note 21 , at 843 . And, while the linguistic analysis may technically be correct, the court is ignoring the functional similarity between a loan of money and a loan of credit, the economic incidents being equivalent. See generally, Berger, Usury in Installment Sales, 2 LAw \& Contemp. Prob. 148 (1935). But cf. Ecker, Commentary on "Usury in Installment Sales," 2 LAw \& Contemp. PRoB. 173 (1935).

46. The earliest American case is Hogg v. Ruffner, 66 U.S. (1 Black) 115 (1861). See also Van Asperen v. Darling Olds Inc., 254 Minn. 62, 93 N.W.2d 690 (1958). For a general discussion on the applicability of usury laws to revolving credit, see Consumer Credit Symposium, supra note 13, at 336-39.

47. When there is merely a buyer and a seller, such similarity is, perhaps, obscure, yet it exists when one looks to the economic position of the parties. The buyer, whether receiving a loan of money or credit, does not pay for the goods with cash taken from savings or current income; he may repay in installments in either case; and he pays a charge for the privilege of receiving the goods now instead of later. The seller, while not giving money to the buyer, must give money to the manufacturer on behalf of the buyer, and, as with a loan of money, he receives money from the buyer for the extension of credit. The entrance of the third party financer makes the distinction nonsensical: it is difficult to perceive the difference between a loan of money from a bank to a consumer for the purchase of a car and an installment sales contract which is eventually held by a bank; in both cases, the consumer will probably be paying installments to the bank; in many cases, the arrangements are made directly with the bank. See Phelps, Financrng the Instaliment Purchases of the American Family 32-33 (1954). 
see if the time price is a bona fide one. ${ }^{48}$ Where they find a pre-existing relationship between finance company and seller, ${ }^{40}$ or finance company and buyer, ${ }^{50}$ these courts have held the transaction subject to the usury laws. Inquiry into the bona fide character of the time sale has taken another aspect; if it appears that the "time price" is merely a service charge to be computed on the basis of the cash price rather than a fixed sum initially bargained for, the transaction will be viewed as a device to hide interest rates and will be found subject to the usury laws. ${ }^{51}$

It can readily be seen that the new credit card plans fall within the exceptions to the time-sale doctrine. There is both a seller-financer and buyerfinancer arrangement before a purchase is made. No time price is given at the time of purchase, for the buyer is free to pick his own terms within the framework of the pre-existing agreement with the financer. In the jurisdictions adopting these exceptions to the time-sale doctrine, therefore, the new credit card plans may be placed under usury law regulation; some state banking commissioners have suggested that this is a possibility in their jurisdictions. ${ }^{52}$

48. See, c.g., Hare v. General Contract Purchase Corp., 220 Ark. 601, 249 S.W.2d 973 (1952); State $e x$ rel. Beck v. Associates Discount Corp., 162 Neb. 683, 77 N.W.2d 215 (1956). The Hare case and subsequent Arkansas cases have, in effect, eliminated the time-sale doctrine in that state. See Consumer Credit Symposinm, supra note 13, at 305-06.

49. See, e.g., Hare v. General Contract Purchase Corp., supra note 48; Nazarian v. Lincoln Finance Corp., 77 R.I. 497, 78 A.2d 7 (1951).

50. First Nat'l. Bank v. Daniel, 239 F.2d 301 (5th Cir. 1956).

51. Ibid. See also State ex rel. Beck v. Associates Discount Corp., 168 Neb: 803, 97 N.W.2d 583 (1959).

The courts, by looking through the time-sale theory, have not explicitly repudiated the theory that a loan of credit is different from a loan of money, but rather have stated that such transactions are in reality loans of money hidden by a sales contract. Such an approach has been criticized as heaping one fiction upon another. Warren, supra note 21 , at 845,849 . The effect of seeing installment sales as loans of money has prevented passage of a valid retail installment sales act in Nebraska, where a state constitutional provision forbids special legislation for any lenders of money. See Stanton v. Mattson, Neb., Oct. 18, 1963, discussed in Wall Street Journal, Oct. 23, 1963, p. 1, col. 2.

52. It is apparent that some state enforcement officers are in disagreement as to which laws should apply. A number of state authorities assert that the usury laws govern the transaction. Letter from C. V. Pierce, Chief Examiner, South Carolina Bd. of Bank Control, Oct. 15, 1963; letter from F. L. Harrelson, Deputy Comm'r of Banks, North Carolina Banking Dep't, Oct. 14, 1963; letter from W. M. Jackson, Acting Superintendent of Banks, Georgia Dep't of Banking, Oct. 7, 1963. Others believe that the usury statutes along with the small loan act and the retail installment sales act apply. Letter from J. Hospelhorn, Deputy Bank Comm'r, Maryland State Banking Dep't, Oct. 8, 1963; letter from S. Hoshimoto, Bank Examiner, Hawaii Div. of Bank Examination, Oct. 10, 1963. Another states that the usury statute and the retail installment sales act apply. Letter from A. Lingle, Director of the Div. of Banking and Securities, Alaska Dep't of Commerce, Oct. 28, 1963. Others feel that none of the existing laws should apply. Letter from G. L. Robison, Superintendent of Banks, Nevada Banking Dep't, Oct. 4, 1963; letter from W. Ewald, Supervisor, Small Loan Div., Iowa Dep't of Banking, Oct. 8, 1963. See also Doyle, Charges for Revolving Credit and Charge Accounts, 12 Personal Finance L.Q. 
True, the trend toward adoption of the exceptions in dealing with installment sales transactions has slowed - if not ceased - with the advent of legislation specifically oriented to these transactions. But the emergence of a new financing device, to which the legislature has not yet spoken, could well prod judges to revive this case-law trend.

In addition to the usury laws, revolving credit accounts might be regulated under installment loan acts ${ }^{53}$ and small loan acts. ${ }^{54}$ Such legislation was passed in recognition that the maximum rates of usury laws were unreasonably low when applied to loans of a small amount. ${ }^{55}$ Installment loan acts were directed at banks making small loans, ${ }^{56}$ and small loan acts at other money-lending institutions. ${ }^{57}$ The former, like usury laws, set a maximum permissible return to the lender and require only contractual disclosure of the rate of interest to be charged ;8 these acts may apply to the new plans for the same reasons the usury laws may apply. ${ }^{59}$ Small loan acts, which limit the total charges that may be assessed, ${ }^{60}$ have strict disclosure requirements ${ }^{61}$ and prohibit REPORT 33, 67 (1958), where a bank supervisor concludes that revolving credit plans are regulated presently by both usury law and small loan act.

The Attorney General of Pennsylvania has asserted that three-party revolving credit arrangements in which banks are issuers are governed by the general usury statute when a loan of more than $\$ 3500$ is involved and by the special usury statute for smaller loans made by banks when the amount is less. Penn. Attorney General, Official Opinion No. 231, Dec. 1960.

53. See, e.g., Iowa Cone ANN. $\S \S 529.1-529.13$ (1949). See generally Consumer Credit Sympasium, supra note 13, at 310-13.

54. See, e.g., Cad. Finance Code $\$ \S 24000-24651$.

55. The small loan acts represented the legislative response to the loan-shark problem. By raising permissible maximum rates, the legislatures attempted to provide legitimate lenders with the opportunity of making a reasonable profit for the extension of small loans to poor credit risks. See generally, RoBINson \& NUGENT, REGULATION OF THE Smald Loan Business (1935); Bogert, The Future of Small Loan Legislation, $12 \mathrm{U}$. Chi. L. Rev. 1 (1944).

It is interesting to note, however, that merely raising maximum rates does not ensure the extension of credit to poor risks. Ienders may simply raise the interest rate and extend credit to better risks. However, as evidenced by the decline of the "loan-shark" problem, the effect of small loan acts has been the attainment of that goal.

As to the installment loan acts, it might appear that there has been no change in maximum rates; in New York, for example, the usury law maximum is $6 \%$ and the installment loan law maximum is $6 \%$. Compare N.Y. GEN. Bus. LAw art. $25, \S 370$, to be replaced by N.Y. Gen. Obirgations LaW art. 5, § 501 (Cum. Supp. 1963) (effective Sept. 27, 1964), with N.Y. BankING LAw art. 3, \$ 108 (Cum. Supp. 1963). However, the installment loan act provides that interest may be computed on the total amount as opposed to computation on the declining principal balance. The net effect is that the rate is approximately doubled for the installment loan act.

56. See, e.g., Iowa Code ANn. \& 529.2 (1949).

57. See, e.g., CAL. Finance Code $\S 24050$.

58. See, e.g., Iowa CODE ANn. \& 529.6 (1949).

59. See notes 51-52 supra and accompanying text.

60. "Charges" under the small loan acts are all inclusive and thus not limited to "interest," so that everything but filing fees and insurance charges which are identifiable are generally included. See, e.g., CAL. Finance Code $\$ \S 24003,24455$.

61. See, e.g., CaL. Finance Code $\$ \S 24469,24470$. 
certain "unfair" contractual provisions. ${ }^{62}$ These usually regulate loans of credit as well as money; $;^{63}$ even when they do not refer specifically to loans of credit, comparison between credit extensions under the new plans and small loans is inevitable. The original line of credit given in the card plans fits under the jurisdictional ceilings of the acts $;^{64}$ in both loans costs are high because of risk and the small amount of credit or money loaned ${ }^{65}$ the ultimate purchasing power created by the credit transactions is directed toward similar ends. ${ }^{6 B}$

Ironically, retail installment sales acts, ${ }^{67}$ specifically passed to regulate loans of credit in installment sales, appear less applicable to the new credit card plans than the statutes regulating loans of money. In retail installment sales acts, maximum rates are stipulated, ${ }^{68}$ protection against fraudulent practices is provided through disclosure, ${ }^{69}$ and certain contract rights are protected against waiver or case law diminution. ${ }^{70}$ However, many of the acts are limited to motor vehicle sales financing. ${ }^{71}$ The majority of the remaining acts

62. See, e.g., Caz. Finance Code $\$ 24468$.

63. See, e.g., Cal. Finance Code $\S \S 24003,24007$.

In Master Charge v. Daugherty, 123 Cal. App. $2 d 700,267$ P.2d 821 (1954), it was held that a three-party credit card plan was restricted by the rate provisions and the licensing provisions of the small loan act, inasmuch as it was a loan of credit. The plan did not operate on a revolving account basis but rather involved a yearly charge of $\$ 5$. However, shortly thereafter the California legislature amended the act to exempt some credit card plans from its operation. CAL. FIN. CODE $§ 24051.1$ (Supp. 1963). The exclusion does not relate to revolving account credit card plans inasmuch as it is limited to plans in which a yearly charge of less than $\$ 10$ is made. CAL. Fin. CodE $\S 24051.1(\mathrm{~b})$ (Supp. 1963).

64. Small loan maximums vary, ranging from $\$ 300$ to $\$ 1000.1 \mathrm{CCH}$ INSTALLMENT CREDIT GUIDE $\llbracket 41$ (1963). The amount of credit granted under the new credit card plans is within the same range.

65. The high cost of providing small loans was one of the motivating factors in the passage of small loan legislation. The costs of providing credit in the new credit card plans are "notoriously" high. See Financial World, Jan. 4, 1961, pp. 7-8.

66. Compare Natronal Consumer Finance Association, op. cit. supra note 31, at 11-12, with Fact Sheet.

67. The retail installment sales acts are recent additions to the growing spectrum of consumer protection legislation. They were prompted by the abuses prevalent in the industry, which became pronounced with the great increase in installment sales since World War II, and by the unwillingness of courts to apply usury law rates to such transactions. See Warren, supra note 21, at 841. Another possible reason for the passage of such legislation may have been the fear that the courts would apply the usury laws to installment sales in the future, prompting installment sales finance companies to sponsor the legislation.

68. See, e.g., Cal. CrvmL Code $\S \S 1805.1-1805.5$. See generally, 1 CCH InstallMIEnt Credit Guide đ 35 (1963).

69. Disclosure provisions usually require the seller: to use large face type to warn the consumer that he is signing a retail installment contract; to specify the cash price, the time price, and service charges (both in percentage and cash terms). Maximum rates are generally provided on a dollar per $\$ 100$ per year basis. See, e.g., CaL. CIVIL CoDE $\S \S$ 1803.3-1803.9.

70. See, e.g., CAL. Civir Cone \$§ 1804.1-1804.4.

71. See, e.g., Mass. Ann. Laws ch. 255B, §§ 1-24 (Supp. 1963). 
apply only to conditional sales or other secured transactions. ${ }^{72}$ Under the credit card plans, security interests in the goods purchased cannot with practicality be obtained..$^{73}$ Further, the acts refer only to "buyer-seller" transactions, ${ }^{74}$ omitting reference to any third party. Although merchants usually sell retail installment contracts to finance companies, the buyer-seller bargain is the essential part of the transaction. Not so under the new credit card plans, where the issuer-buyer contract is the fundamental credit arrangement. ${ }^{75}$

Existing legislation, though it seems to deal with many of the problems presented by revolving credit plans, is not well fitted for the task. None of these statutes focuses upon disclosure problems inherent in the revolving credit plans. For example, retail installment sales acts, even if amended to include arrangements between financers and buyers, would be ineffective instruments of policy without a complete amendment of their disclosure provisions. Focusing upon the single purchase situation, they require total finance charges and total costs of the goods bought to be set out in the contract. ${ }^{76}$ When revolving credit accounts are used, it is impossible to determine at the time of the initial agreement how much will be spent for the range of goods offered and, therefore, what their total cost will be. It is likewise impossible to determine the cost of credit, for the borrower is able, by varying his monthly payments, to control the amount on which the service charge will be levied. The usury. laws and installment loans are less satisfactory, for they provide only a minimum disclosure, the only requirement being that the interest rate be set out in a contract. ${ }^{77}$ The disclosure provisions of the small loan acts require more information - for example, the dollar-cost of the loans - but this information, again, cannot be given at the time of the initial credit card agreement or at any time when credit is used. None of the present acts require such necessary information as monthly statements, disclosure of the maximum amount of credit extended, and the fact that the charge must be computed on a monthly, declining balance basis.

The uniqueness of the revolving credit plan is even more clearly discernible when the question of rate maximums is at issue. Analytically, imposition of rate ceilings seems unnecessary. ${ }^{78}$ But such rate ceilings exist and may be applied to revolving credit plans. ${ }^{79}$ The determination of what rate is reason-

72. See, e.g., Ill. Rev. Stat. ch. 1211/2, § 1 (Supp. 1963).

73. See note 13 supra.

74. See, e.g., Irl. Rev. Stat. ch. 1211/2, §§ 1-2 (Supp. 1963).

75. Statutes frequently allow sales of installment sales contracts to finance companies, but a single purchase transaction is contemplated - only the one buyer-seller transaction and the one relationship between the buyer and the finance company arising from that purchase is involved. See, e.g., CAL. Crvil Code $\S 1809-1$. Such provisions are, therefore, not applicable to the new credit card issuers.

76. See, c.g., CAL. Civil Code $\$$ 1803.3-1803.9.

77. See discussion in notes 41 \& 43 supra.

78. See notes 23-36 supra and accompanying text.

79. Although it may seem clear that rate ceilings are undesirable, the possibility of repeal of such existing laws is smail, due to the emotive content of usury issues and 
able is, however, extremely complex and depends on the type of transaction involved. Cost factors, including risk extensions, must be set off against the issuer's income from the total credit transaction. Under the new plans cost per dollar is high. If issuers fell under the usury law rates, a fair return would be improbable. ${ }^{80}$ Of course, the profits made in discounting transactions with merchants enable the issuers to operate at rates much lower than those which are allowed by small loan acts. ${ }^{81}$

\section{The New York Statute}

What is needed then, is legislation tailor-made for this particular type of credit transaction. A recent New York statute, ${ }^{82}$ amending the retail installment sales act to include three-party revolving credit transactions, may provide a model for other states. ${ }^{83}$ It is specifically oriented to revolving credit trans-

political responses to consumer feelings. However, if repeal of existing legislation cannot be had, it is hoped that rate ceilings will not be extended to new forms of consumer finance as an automatic legislative response.

80. It has generally been asserted that an application of usury law rates will render installment selling impractical. See Wall Street Journal, Oct. 23, 1963, p. 1, col. 2, p. 22, col. 1. Similarly, an application of usury rates to the new credit card plans would be unreasonable, inasmuch as the cost-income differential is similar to that in ordinary installment sales. See Phelps, Financing the Installment Purchases of the American FAMILY 45 n. 150 (1954).

81. While most plans operate with a charge of $11 / 2 \%$ per month, the permissible rates under the small loan statutes vary from $2 \%$ to $3 \frac{1}{2} \%$. See $1 \mathrm{CCH}$ INSTALLMENT CRedit Guide II 41 (1963).

It is difficult to determine whether the rates prescribed by the retail installment sales acts are reasonable in regard to revolving credit rates, for it is difficult to find the cost factors involved in the new plans (although legislatures obviously could do so). Many of such acts allow a greater percentage charge than issuers currently make. See, e.g., N.Y. Pers. Prop. Law art. 10, § 404 which allows a charge of $\$ 10$ per $\$ 100$ loaned per year "true interest" of approximately $20 \%$ inasmuch as the loan is repaid in installments over the yearly period (thus the borrower has the "use" of the money for only half the time).

As to protection of contract rights, it is equally clear that the existing laws are inadequate. The usury laws contain none; the small loan acts generally prohibit only the assignment of wages; the retail installment sales acts, while adding prohibitions against waivers of defenses against sellers, fail to deal with the special problems which arise because of the important function of the issuer.

82. N.Y. Pers. Prop. Law art. $10, \S 413(11)$ (1962). Section 413 regulates all revolving credit transactions, but $\S 413(11)$ adapts the measures to a three-party arrangement; it does not specifically mention "credit cards," but it obviously looks to arrangements such as the new plans.

83. A few other states have statutes regulating revolving credit arrangements in general without distinguishing between two- and three-party arrangements but which might be interpreted to apply to the tripartite plans. See, e.g., CAL. CIv. CoDE $\$ \S 1810.1-.11$ (Supp. 1963) ; DeL. ANN. Code tit. 6, §§ 4334-4343 (Supp. 1962). Such statutes generally refer only to a "buyer" and a "seller," the only reference to finance companies being a section which allows them to purchase the seller's revolving accounts. See, e.g., CaL. CIv. Cone $\S 1809.1$ (Supp. 1963). Such specific language must be ignored if the acts are to apply to the new plans. See Comment, The Tripartite Credit Card Transaction, 48 CALIF. L. REv. 459, 494-98 (1960), where the author concludes that coverage will not be extended. 
actions in its approach to disclosure and contract terms, as well as a maximum charge rate. The disclosure requirements of the law focus on preventing fraud and providing the holder with the details of the agreement. ${ }^{84}$ Initially, the holder must be informed, in eight to ten point type, that he is entering a "retail installment credit agreement," which must be set out in full in the initial issuerholder agreement and a copy of which must be provided to the holder. $\mathrm{He}$ must also be provided with a monthly statement which is to show: the balance due to the issuer; the dollar amount of each purchase; a description of each purchase, the date of purchase, and its cash purchase price, unless these items have previously been furnished by the seller to the buyer; the payments made and other credits received during the monthly period; the amount of the service charge; and a legend informing the buyer that he may at any time pay his total indebtedness. Under the law, no retail installment credit agreement may contain any of the following provisions, deemed to be unfair :85 allowing the issuer to accelerate the maturity of the debt unless the holder defaults; allowing confession of judgment or assignment of wages; waiving a right of action for illegal acts in collection of payment or any right given under the act; appointing the issuer or its agent as the holder's agent in collection of payments; or relieving the seller from liability for any legal remedy which the buyer may have against him. Finally, the New York legislation prescribes maximum rates which may be charged by the issuer for the extension of credit to the holder :86 $1-1 / 2 \%$ per month on the unpaid balance for accounts up to $\$ 500$ and $1 \%$ per month for any excess in indebtedness over $\$ 500$; a minimum charge of $\$ .70$ per month is allowed.

The New York act, however, is a model which suffers from some deficiencies. The issuer should be forced to set out clearly in the initial agreement that the service charge is levied on the amount of credit outstanding once the monthly payment is made rather than on the credit line available or actually used. ${ }^{87}$ And, the holder should be informed of the maximum amount of credit

See also Opinion No. 060-4 of the Attorney General of Florida, Jan. 11, 1960, which asserts that the new credit card plans are essentially merchandising agreements between the bank and the seller, since the merchant is paid immediately and not in installment payments, so that the revolving credit act does not apply to the transaction.

84. N.Y. Pers. Prop. LAw art. $10, \S 413(2,4)$.

85. N.Y. Pers. Prop. LAW art. 10, § 413(10) (Cum. Supp. 1963).

86. N.Y. Pers. Prop. LaW art. 10, § 413(3).

87. Furthermore, the legislation does not differentiate the plans which offer loans of money as well as credit, and there is some suggestion that a loan of money requires an additional charge to be added on. When borrowing money via "BankAmericard," the consumer is charged $4 \%$ immediately for the loan, 'and then the amount of the loan plus the $4 \%$ are placed on the revolving account. Fact Sheet. This, in turn, presents a problem under the California revolving credit act. CAL. CIv. CoDE $\$ \S 1810.1-11$ (Supp. 1963). Section 1810.6 provides that "the service charge shall include all charges incident to investigating and making the retail installment account. No fee, expense, delinquency, collection or other charge whatsoever shall be taken . . . by the seller or holder of a retail installment account. . ." Section 1810.4 limits charges to $11 / 2 \%$ per month on 
available to him. More steps could be taken to ensure that the card holder reads the terms of the agreement - for example, by requiring signature at the end of the form, or informing the holder not to sign before reading. At present, "negotiations" are often conducted by mail, with the would-be holder submitting an application on a form containing the terms of the contract. The opportunity for clarification, at least a possibility in face-to-face encounters, virtually disappears. It is important to note, however, that disclosures of costs is effective for rate reduction only if there is uniform disclosure of rates in all types of lending transactions. ${ }^{88}$ Customers should be able to compare readily the relative costs of the various avenues of credit offered.

More troublesome is the penalty provision of the New York statute, ${ }^{89}$ an unfortunate betrayal of the role the credit industry played in the drafting of the legislation. Although substantive provisions appear to give major protection to consumer interests, the remedies granted for violation of the substantive norms are such as to render this protection ineffective. Thus, a wilful infraction is punishable only by a five hundred dollar fine, as a misdemeanor $\mathbf{; 0}^{\mathbf{9 0}}$ the act in no way provides for filing of forms, special enforcement officials, or other means of keeping track of issuer activities. Nor is the holder likely to be a source of enforcement action, for he can recover only the total amount of the service charge levied against him (even if the infraction is other than excess charges).$^{91}$ Since the expense of a lawsuit is large and its inconvenience great, holders are unlikely to take any affirmative action against an issuer who is in violation of the act. Similarly, if the holder alleges issuer violation

balances up to $\$ 1000$ and to $1 \%$ per month on balances over $\$ 1000$. If the act is construed to regulate tripartite plans, therefore, it is apparent that the additional charge of $4 \%$ is in violation of the act.

88. At present, no state prescribes a uniform method of quoting charges on loans of money and credit. See generally, Phelps, Monopolistic and Imperfect Competition in Consumer Loans, 8 J. of Marketing 382 (1944), and Young, Personal Finance Conpanies and Their Credit Practices 18, 159 (1940); both authors conclude that uniform methods of quoting rates would make competition more effective. At present, a bill is pending before the Senate which prescribes a uniform method of disclosure through "true simple interest" rates. See "Truth in Lending" Bill, S. 750, 88th Cong., 1st Sess. (1963); section (b) of the bill is specifically directed at revolving credit. For views pro and con, see generally Hearings Before a Subcommittee of the Senate Committee on Banking and Currency on S. 2755, 86th Cong., 2d Sess. (1960) and Hearings Before a Subcommittee of the Senate Committee on Banking and Currency on S. 1740, 87th Cong., 2d. Sess. (1962).

89. N.Y. Pers. Prop. Law art. 10, § 414.

90. N.Y. Pers. Prop. LAW art. 10, \& 414(1) provides:

Any person who shall wilfully violate any provision of this article shall be guilty of a misdemeanor and upon conviction shall be punished by a fine not exceeding five hundred dollars.

91. N.Y. Pers. Prop. Law art. 10, $\$ 414(2)$ provides:

In case of failure by any person to comply with the provisions of this article, the buyer shall have the right to recover from such person an amount equal to the credit service charge or service charge imposed and the amount of any delinquency, collection, extension, deferral, or refinance charge imposed. 
of the act as a defense in an action against him on his debt, it seems likely that the defense will be good only as to the service charge and not as to principal. ${ }^{22}$ The ineffectiveness of the remedies provisions is accentuated by a provision which permits the issuer to avoid both the criminal and civil penalties by a novation, that is, by correcting the deviation in the particular contract within 10 days after notification from the holder ${ }^{93}$ Finally, enforcement only occurs on a single contract basis. In an area in which use of form contracts is inevitable, so that deviations from the statutory norm will be multiplied and remultiplied, the state, to secure deletion of an objectionable clause from a contract form, must threaten a misdemeanor suit on each contract issued.

All of these weaknesses in enforcement could be easily corrected. Through filing requirements there would be automatic access to contracts, and through approval procedures, the power to expunge deviating clauses can be obtained. A specific agency with its eye trained on broad practices seems likely to be a more effective enforcer than the attorney general vindicating a misdemeanor interest in individual violations. The misdemeanor penalty, which presently has little more than nuisance value, could be dropped. If it is retained, the fine should be increased. Holder enforcement is another area for reform. While forgiveness of the holder's debt upon showing of the issuer's wilful violation may be too extreme a remedy, a treble service charge damage recovery might make holder enforcement more likely, prompting the issuer to use more care to avoid violations. ${ }^{94}$ Finally, novation treatment should be revised. Where the issuer's error is clerical, or otherwise associated with but one contract, a court may be satisfied by novation of that contract alone. But if the deviation is characteristic of a given form contract, a novation should not be implied until a court is satisfied that all affected contracts have been reformed and effective action has been taken to prevent recurrence. ${ }^{95}$

92. Note 90 supra.

93. N.Y. PERS Prop. LAW art. 10, § 414(3) provides:

Notwithstanding the provisions of this section, any failure to comply with any provision of this article may be corrected within 10 days after the holder is notified thereof in writing by the buyer and, if so corrected, neither the seller nor the holder shall be subject to any penalty under this section.

94. Recovery of double or triple interest is presently allowed in a number of states for violation of usury laws. See, e.g., IOWA CODE ANN. $\$ 535.3$ (1962).

95. In either case, once novation is shown to have occurred, damages or set off should be limited to injury actually suffered by the holder by reason of the tainted clause. 